\title{
Catalysis of organic pollutant photodegradation by metal phthalocyanines immobilized on $\mathrm{TiO}_{2} @ \mathrm{SiO}_{2}$
}

\author{
WANG ShuLian ${ }^{1}$, FANG YanFen ${ }^{1}$, YANG Yong ${ }^{2}$, LIU JunZi ${ }^{1}$, DENG AnPing ${ }^{1}$, \\ ZHAO XiaoRong ${ }^{1} \&$ HUANG YingPing ${ }^{1 *}$ \\ ${ }^{1}$ Engineering Research Center of Eco-environment in Three Gorges Reservoir Region, Ministry of Education, China Three Gorges University, \\ Yichang 443002, China; \\ ${ }^{2}$ Shanghai Institute of Ceramics, Chinese Academic of Sciences, Shanghai 200050, China
}

Received July 23, 2010; accepted September 30, 2010

\begin{abstract}
A $\mathrm{TiO}_{2} @ \mathrm{SiO}_{2}$ hybrid support was prepared by the sol-precipitation method using $n$-octylamine as a template. The photocatalyst manganese phthalocyanine tetrasulfonic acid $(\mathrm{MnPcS})$ was immobilized on the support to form $\mathrm{MnPcS}_{-} \mathrm{TiO}_{2} @ \mathrm{SiO}_{2}$. X-ray diffraction (XRD) and UV-Visible diffuse reflectance spectra (UV-Vis DRS) were employed to characterize the catalyst. The photocatalytic degradation of rhodamine $\mathrm{B}(\mathrm{RhB})$ and the catalytic oxidation of $o$-phenylenediamine (OPDA) under visible light irradiation were used as probe reactions. The mineralization efficiency and the degradation mechanism were evaluated using chemical oxygen demand $\left(\mathrm{COD}_{\mathrm{Cr}}\right)$ assays and electron spin resonance (ESR), respectively. RhB was efficiently degraded by immobilized $\mathrm{MnPcS}-\mathrm{TiO}_{2} @ \mathrm{SiO}_{2}$ under visible light irradiation. Complete decolorization of RhB occurred after 240 min of irradiation and $64.02 \% \mathrm{COD}_{\mathrm{Cr}}$ removal occurred after $24 \mathrm{~h}$ of irradiation. ESR results indicated that the oxidation process was dominated by the hydroxyl radical $(\cdot \mathrm{OH})$ and superoxide radical $\left(\mathrm{O}_{2}^{-}\right)$generated in the system.
\end{abstract}

manganese phthalocyanine tetrasulfonic acid, $\mathrm{TiO}_{2} @ \mathrm{SiO}_{2}$, photocatalytic degradation, hydroxyl radical, superoxide radical

Citation: Wang S L, Fang Y F, Yang Y, et al. Catalysis of organic pollutant photodegradation by metal phthalocyanines immobilized on $\mathrm{TiO}_{2} @ \mathrm{SiO}_{2}$. Chinese $\mathrm{Sci}$ Bull, 2011, 56: 969-976, doi: 10.1007/s11434-010-4280-3

Metal phthalocyanines (MPc) can strongly absorb visible light or sunlight [1], and consequently have attracted interest for visible light photocatalytic degradation of toxic organic pollutants [2]. However, MPc are unstable and are easily degraded by the hydroxyl radical $(\cdot \mathrm{OH})$ and other highly reactive species. They also tend to aggregate in water due to excitation by visible light which greatly reduces photocatalytic activity because the excited energy states of aggregated MPc are offset by non-excited states, and overall the photocatalytic activity is greatly reduced. Enhancing the stability and the dispersion of MPc is a prerequisite to full exploitation of their photocatalytic activity [2]. Immobilization can stabilize MPc against

\footnotetext{
*Corresponding author (email: huangyp@ctgu.edu.cn)
}

oxidation [3] while inhibiting aggregation by ordering crystal packing and localizing internal spaces [2]. Under these conditions, molecules of MPc are in the dispersed state and have good photocatalytic activity. Supports that eliminate aggregation of MPc on the surface have been reported in the literature, and include resin IRA900 [1], $\mathrm{SiO}_{2}$ [4], $\mathrm{Al}_{2} \mathrm{O}_{3}$ [5], and anionic clay [6].

Because degradation of toxic organic pollutants by $\mathrm{TiO}_{2}$ has many advantages [7,8], improving the catalytic properties of $\mathrm{TiO}_{2}$ is of importance [9]. The introduction of $\mathrm{SiO}_{2}$ improves the photocatalytic activity and thermal stability of $\mathrm{TiO}_{2}$ and increases the optical quantum efficiency of the catalytic chemical processes [10]. Furthermore, $\mathrm{SiO}_{2}$ can increase the adsorption of organic compounds by strong acid sites on the $\mathrm{TiO}_{2}$ surface, and the specific 
surface area of the $\mathrm{TiO}_{2}$ particles. $\mathrm{TiO}_{2} @ \mathrm{SiO}_{2}$ is a catalytic material with high specific surface area and activity [10]. The optical absorption of $\mathrm{TiO}_{2} @ \mathrm{SiO}_{2}$ is the same as that of $\mathrm{TiO}_{2}$.

In addition to characterizing the stability and dispersion of the MPc immobilized on $\mathrm{TiO}_{2} @ \mathrm{SiO}_{2}$, the range of light and $\mathrm{pH}$ response of the catalyst was investigated. A photocatalyst with an extended visible light range would more fully degrade toxic organic pollutants. The novel immobilized catalyst $\mathrm{MnPcS}-\mathrm{TiO}_{2} @ \mathrm{SiO}_{2}$ was synthesized and characterized and its effectiveness in the photodegradation of nonbiodegradable pollutants was demonstrated.

\section{Experimental}

\subsection{Materials}

Phthalocyanine tetrasulfonic acid ( $\mathrm{PcS})$ was purchased from J\&K Scientific Co. Tetrabutyl titanate (TBOT), tetraethyl orthosilicate (TEOS) and $n$-octylamine (OA) were obtained from Chemical Reagent Beijing Co., Ltd. 5,5-Dimethyl-1pyrroline-N-oxide (DMPO) was obtained from Sigma-Aldrich Co. IRA200 was obtained from Tianjin Nankai Hecheng S\&T Co., Ltd. Aqueous solutions of rhodamine B $(\mathrm{RhB})$ and $o$-phenylenediamine (OPDA) were used at $5.00 \times 10^{-4}$ and $3.00 \times 10^{-3} \mathrm{~mol} / \mathrm{L}$, respectively. All chemicals were of analytical reagent grade and were used without further purification. The $\mathrm{pH}$ of the solution was adjusted with either $\mathrm{NaOH}$ or $\mathrm{HClO}_{4}$. Deionized and doubly distilled water was used throughout this study.

\subsection{Preparation of $\mathrm{TiO}_{2} @ \mathrm{SiO}_{2}$ nanoparticles}

TBOT (5 mL) was added to $\mathrm{HCl}(30 \mathrm{~mL}, 1.0 \mathrm{~mol} / \mathrm{L})$ to obtain solution A. Solution B was produced by mixing TEOS $(10.0 \mathrm{~g})$ and $n$-octylamine $(8.0 \mathrm{~g})$. A white precipitate formed on when solution A was added dropwise to solution $\mathrm{B}$ with stirring at $50^{\circ} \mathrm{C}$. After centrifugation, the precipitate was washed several times with distilled water and ethanol, dried and calcined at $550^{\circ} \mathrm{C}$ to yield $\mathrm{TiO}_{2} @ \mathrm{SiO}_{2} . \mathrm{TiO}_{2}$ and $\mathrm{SiO}_{2}$ were also synthesized using this method without the addition of TEOS or TBOT, respectively.

\subsection{Preparation of manganese phthalocyanine tetra- sulfonic acid (MnPcS)}

A round-bottom flask $(50 \mathrm{~mL})$ containing $50 \mathrm{mg}$ of $\mathrm{PcS}$ dissolved in $30 \mathrm{~mL}$ of distilled water and $20 \mathrm{mg}$ of $\mathrm{MnSO}_{4} \cdot \mathrm{H}_{2} \mathrm{O}$ was heated at $100^{\circ} \mathrm{C}$ with continual stirring. The reaction solution was extracted at different intervals and its absorbance measured at 200-900 $\mathrm{nm}$. Changes in the absorbance values and the appearance of new absorption peaks were observed. When changes in the Q- and B-band of $\mathrm{PcS}$ were no longer observed the reaction was stopped.
Excess $\mathrm{Mn}^{2+}$ was removed using cation exchange resin (IRA200). The final product was $2.00 \times 10^{-3} \mathrm{~mol} / \mathrm{L} \mathrm{MnPcS}$.

\subsection{Preparation of $\mathrm{MnPcS}-\mathrm{TiO}_{2} @ \mathrm{SiO}_{2}$ complex}

Five different solvents were used as loading solvents, including water, $33 \%, 50 \%$ and $77 \%$ aqueous ethanol, and absolute ethanol. Complex catalysts with 5, 10, 33 and 50 $\mu \mathrm{mol}$ of $\mathrm{MnPcS}$ per gram of $\mathrm{TiO}_{2} @ \mathrm{SiO}_{2}$ support were prepared by mixing $\mathrm{TiO}_{2} @ \mathrm{SiO}_{2}$ powder and $\mathrm{MnPcS}$ in a container for $24 \mathrm{~h}$ under ambient conditions. When the reactions were complete, the used catalysts were separated by filtration, and then washed with water and dried at $80^{\circ} \mathrm{C}$. The used catalysts were then characterized (Section 1.5). $\mathrm{MnPcS}-\mathrm{SiO}_{2}$ and $\mathrm{MnPcS}-\mathrm{TiO}_{2}$ were prepared in the same way as control samples.

\subsection{Catalyst characterization}

The crystalline phases of the samples were characterized by $\mathrm{X}$-ray diffractometry (XRD) (Bruker, Germany) with $\mathrm{Cu} \mathrm{K \alpha}$ radiation. UV-Visible diffuse reflectance spectra (UV-Vis DRS) of the catalysts were recorded on a U-3010 UV-Vis spectrophotometer (Hitachi, Japan) using spectral grade $\mathrm{BaSO}_{4}$ as the reference material.

\subsection{Photocatalytic procedures and analyses}

A 500-W halogen lamp (Institute of Electric Light Source, Beijing) was used as the visible light source. This was positioned inside a cylindrical Pyrex vessel surrounded by a Pyrex jacket with circulating water to cool the lamp. To ensure that the system was irradiated only by visible light $(\lambda>420 \mathrm{~nm})$, any light with $\lambda<420 \mathrm{~nm}$ was completely removed by a cutoff filter (diameter $=3 \mathrm{~cm}$ ). The distance between the reaction vessel and light source was $10 \mathrm{~cm}$.

All the RhB photocatalytic degradation experiments were carried out in a Pyrex vessel $(70 \mathrm{~mL})$ with $1.1 \mathrm{~mL}$ of $\mathrm{RhB}$ $\left(5.00 \times 10^{-4} \mathrm{~mol} / \mathrm{L}\right)$ and $\mathrm{MnPcS}-\mathrm{TiO}_{2} @ \mathrm{SiO}_{2}$. The pH of solution was adjusted to a particular value, and volume was constant at $50 \mathrm{~mL}$. Prior to irradiation, the suspension was stirred in the dark for $30 \mathrm{~min}$ to ensure establishment of dye adsorption/desorption equilibrium on the surface of MnPcS$\mathrm{TiO}_{2} @ \mathrm{SiO}_{2}$. At given irradiation time intervals, $3 \mathrm{~mL}$ of sample was collected, centrifuged, and then filtered through a millipore filter $(0.45 \mu \mathrm{m})$. The filtrates were analyzed using UV-Vis spectroscopy (Perkin Elmer, USA) to examine the decomposition of $\mathrm{RhB}(\lambda=554 \mathrm{~nm})$. Photocatalytic oxidation was also examined using OPDA. OPDA can be oxidized to 2,3-diaminophenazine (DAPN), which has two absorption peaks at 270 and $453 \mathrm{~nm}$ [11]. DAPN is a catalytic oxidation substrate of enzymes such as laccase, horseradish peroxidase, and mimic enzyme [12]. The absorbance changes at $453 \mathrm{~nm}$ were observed to determine the conversion rate of 


\section{OPDA to DAPN.}

Chemical oxygen demand $\left(\mathrm{COD}_{\mathrm{cr}}\right)$ assays were carried out using the potassium dichromate titration method (GB11914-89). A Bruker model EPR 300E spectrometer (Bruker, Germany) equipped with a Quanta-Ray Nd:YAG laser (355 and $532 \mathrm{~nm}$ ) was used for the measurement of radicals spin-trapped by DMPO. Measurement conditions were as follows: center field $3486.7 \mathrm{G}$, sweep width $100 \mathrm{G}$, microwave frequency $9.82 \mathrm{GHz}$, and power $5.05 \mathrm{~mW}$. To minimize experimental errors, the same quartz capillary tube was used for all EPR measurements [13].

\section{Results and discussion}

\subsection{Analysis of MnPcS absorption spectra}

$\mathrm{MnPcS}$ was synthesized using the center direct coordination method [14]. During synthesis, absorption spectra (Figure 1) were measured every $2 \mathrm{~h}$ after initiation of heating and reflux. The UV-Vis spectrum of pure PcS in aqueous solution had a Q-band at $624 \mathrm{~nm}$ and a B-band at $349 \mathrm{~nm} . \mathrm{Mn}^{2+}$ caused a slight change in the Q-band. As the heating progressed, the Q-band red-shifted to $719 \mathrm{~nm}$ and B-band to $510 \mathrm{~nm}$. This occurred due to the coordination of $\mathrm{Mn}^{2+}$ to $\mathrm{PcS}$, which increased conjugation. Similar observations were made by Liang et al [14]. The shift in band position and changes in relative intensity indicated high dispersion and variation in the geometry of $\mathrm{PcS}$ molecules $[15,16]$. However, between the 4 and $10 \mathrm{~h}$, the absorbance values were almost constant, which indicated that preparation of $\mathrm{MnPcS}$ was complete.

\subsection{XRD analysis of catalyst}

The XRD patterns of $\mathrm{MnPcS}-\mathrm{TiO}_{2} @ \mathrm{SiO}_{2}($ Figure 2(A)) and $\mathrm{TiO}_{2} @ \mathrm{SiO}_{2}$ (Figure 2(B)) were used to evaluate the effect of $\mathrm{MnPcS}$ on the crystallinity of $\mathrm{TiO}_{2} @ \mathrm{SiO}_{2}$. The prepared $\mathrm{TiO}_{2} @ \mathrm{SiO}_{2}$ was mainly anatase with characteristic diffraction peaks at $25.11^{\circ}(101), 37.45^{\circ}$ (004), 47.52 ${ }^{\circ}$ (200), $53.99^{\circ}(105)$ and $63.20^{\circ}$ (160). Different amounts of MnPcS

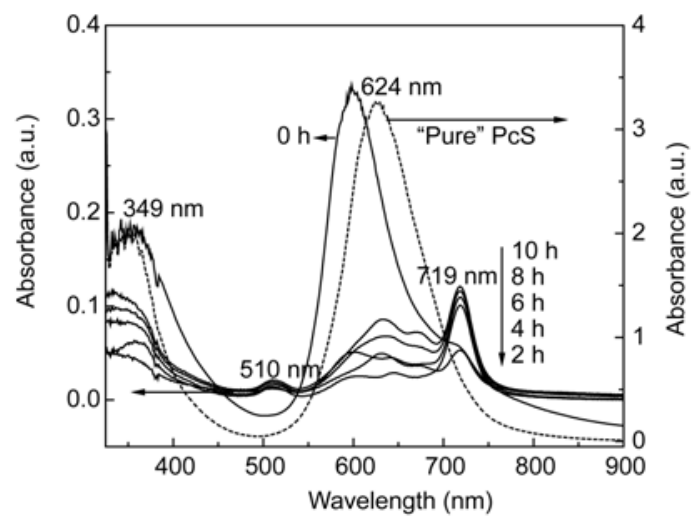

Figure 1 Changes in absorption spectra during the synthesis of MnPcS. supported on the surface of $\mathrm{TiO}_{2} @ \mathrm{SiO}_{2}$ did not change the crystal structure of $\mathrm{TiO}_{2} @ \mathrm{SiO}_{2}$.

\subsection{UV-Vis DRS of catalyst}

The UV-Vis DRS of MnPcS-TiO $\mathrm{TiO}_{2}(10 \mu \mathrm{mol} / \mathrm{g})$ and $\mathrm{TiO}_{2} @ \mathrm{SiO}_{2}$ are shown in Figure 3. The absorption band wavelength shifted to the visible range when $\mathrm{MnPcS}$ was supported on the surface of $\mathrm{TiO}_{2} @ \mathrm{SiO}_{2}$. Furthermore, the absorbance above $400 \mathrm{~nm}$ largely increased for MnPcS$\mathrm{TiO}_{2} @ \mathrm{SiO}_{2}$ (curve a) compared with $\mathrm{TiO}_{2} @ \mathrm{SiO}_{2}$ (curve b).
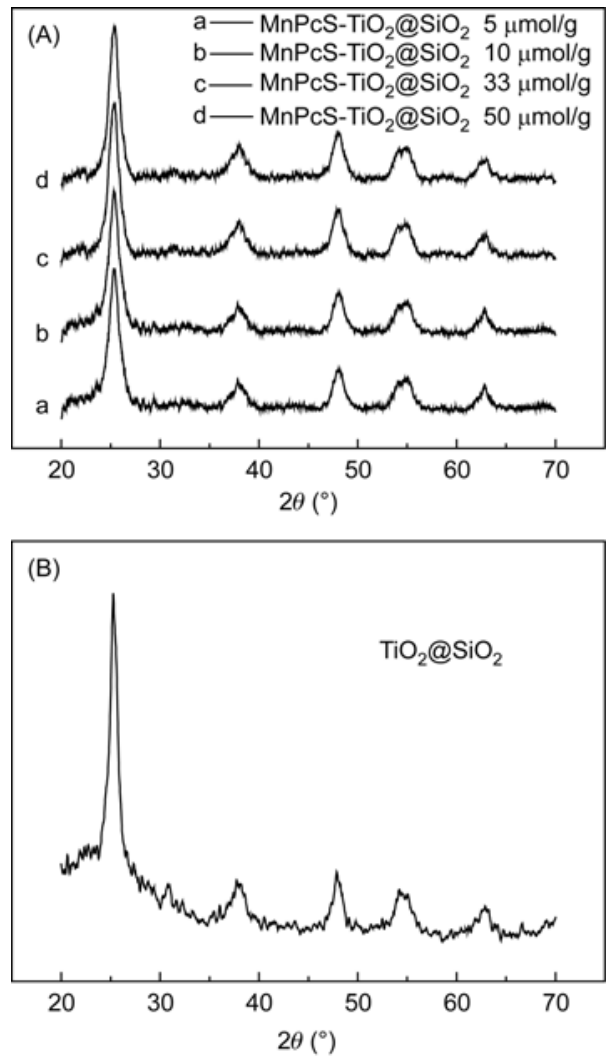

Figure 2 XRD patterns of $\mathrm{MnPcS}-\mathrm{TiO}_{2} @ \mathrm{SiO}_{2}(\mathrm{~A})$ and $\mathrm{TiO}_{2} @ \mathrm{SiO}_{2}(\mathrm{~B})$.

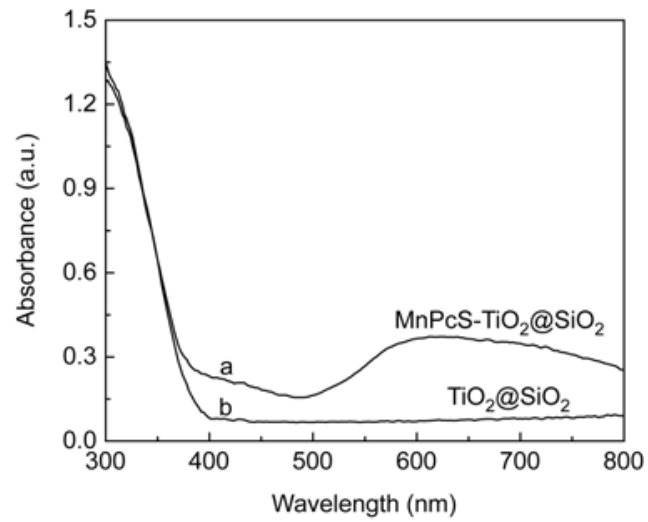

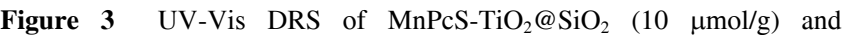
$\mathrm{TiO}_{2} @ \mathrm{SiO}_{2}$. 
Immobilized $\mathrm{MnPcS}-\mathrm{TiO}_{2} @ \mathrm{SiO}_{2}$ facilitated absorption of visible light and broadened the response range to the visible light. This would allow the photocatalytic reaction to occur under visible light irradiation. The higher absorbance observed between 600-800 $\mathrm{nm}$ might be that of MnPcS.

\subsection{Photocatalytic degradation of toxic organic pollutants by immobilized $\mathrm{MnPcS}-\mathrm{TiO}_{2} @ \mathrm{SiO}_{2}$}

(1) Effect of loading solvent. The MnPcS solution tended to aggregate in aqueous solution, and the catalytic activity of the aggregated polymer is lower than the monomer [2]. $\mathrm{Xu}$ et al. [17] found that the catalytic activity of the same dose of catalyst loaded in aqueous ethanol was higher than that loaded in aqueous solution. In ethanol MPc does not tend to aggregate. We investigated the effect of five loading solvents with different ratios of water and ethanol on the degradation of RhB (Figure 4). The catalytic activity in aqueous solution was the lowest (curve a). Gradual increases in the proportion of ethanol increased the catalytic activity (curves b, c, d). The best catalytic activity was obtained with absolute ethanol as the loading solvent (curve e).

(2) Determination of optimal loading amount. The effect of the amount of $\mathrm{MnPcS}$ loaded on $\mathrm{TiO}_{2} @ \mathrm{SiO}_{2}$ on the photocatalytic degradation of $\mathrm{RhB}$ by $\mathrm{MnPcS}-\mathrm{TiO}_{2} @ \mathrm{SiO}_{2}$ was investigated (Figure 5). Catalytic activity first increased and then decreased as the loading amount increased. The photodegradation of RhB under visible light irradiation followed first-order kinetics. With loading amounts of 5, 10, 33 and $50 \mu \mathrm{mol}$ of $\mathrm{MnPcS}$ per gram of $\mathrm{TiO}_{2} @ \mathrm{SiO}_{2}$ support, the degradation kinetic constants $(k)$ were 0.0030 (curve a), 0.0075 (curve b), 0.0035 (curve c) and $0.0027 \mathrm{~min}^{-1}$ (curve d), respectively. A small amount of MnPcS $(5 \mu \mathrm{mol})$ could not fully occupy the surface of $\mathrm{TiO}_{2} @ \mathrm{SiO}_{2}$, while excess $\mathrm{MnPcS}$ (33 and $50 \mu \mathrm{mol}$ ) led to excited state quenching and reduction of degradation. Extra $\mathrm{MnPcS}$ acted as a light filter on the surface of $\mathrm{TiO}_{2} @ \mathrm{SiO}_{2}$, which lowered the light quantum yield and reduced the catalytic activity of $\mathrm{MnPcS}$ -

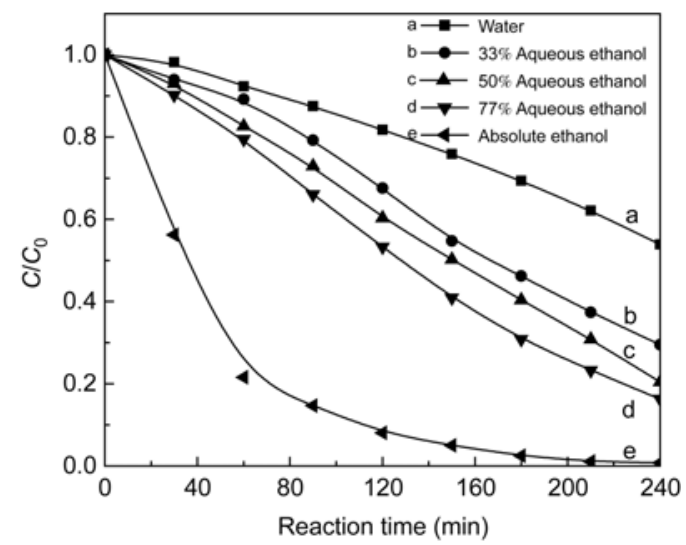

Figure 4 Degradation of $\mathrm{RhB}$ by $\mathrm{MnPcS}-\mathrm{TiO}_{2} @ \mathrm{SiO}_{2}(10 \mu \mathrm{mol} / \mathrm{g})$ prepared in five different solvents. $[\mathrm{RhB}]=1.10 \times 10^{-5} \mathrm{~mol} / \mathrm{L},\left[\mathrm{MnPcS}-\mathrm{TiO}_{2} @ \mathrm{SiO}_{2}\right]=$ $0.20 \mathrm{~g} / \mathrm{L}$, and $\mathrm{pH} 6.88$.

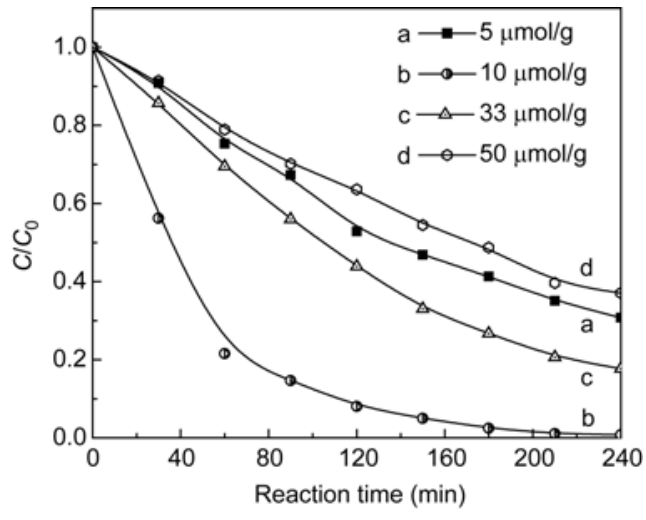

Figure 5 Degradation of $\mathrm{RhB}$ by $\mathrm{MnPcS}-\mathrm{TiO}_{2} @ \mathrm{SiO}_{2}$ with different catalyst loadings. $[\mathrm{RhB}]=1.10 \times 10^{-5} \mathrm{~mol} / \mathrm{L} ;\left[\mathrm{MnPcS}-\mathrm{TiO}_{2} @ \mathrm{SiO}_{2}\right]=0.20 \mathrm{~g} / \mathrm{L}$; pH 6.88 .

$\mathrm{TiO}_{2} @ \mathrm{SiO}_{2}$ [18]. Only $10 \mu \mathrm{mol}$ of $\mathrm{MnPcS}$ per gram of $\mathrm{TiO}_{2} @ \mathrm{SiO}_{2}$ could reduce the $\mathrm{TiO}_{2} @ \mathrm{SiO}_{2}$ particle size and increase the specific surface area, which aided photocatalytic activity. Therefore, this was selected as the optimal loading amount under the experimental conditions. MnPcS$\mathrm{TiO}_{2}$ and $\mathrm{MnPcS}-\mathrm{SiO}_{2}$ with different loading amounts were also synthesized. The results indicated that more $\mathrm{MnPcS}$ was needed to prepare both $\mathrm{MnPcS}-\mathrm{TiO}_{2}$ and $\mathrm{MnPcS}-\mathrm{SiO}_{2}$ with the same loading amount as $\mathrm{MnPcS}-\mathrm{TiO}_{2} @ \mathrm{SiO}_{2}$. The binding of $\mathrm{MnPcS}$ with $\mathrm{TiO}_{2}$ or $\mathrm{SiO}_{2}$ was not as strong as that with $\mathrm{TiO}_{2} @ \mathrm{SiO}_{2}$. Hence, it was easy to wash away $\mathrm{MnPcS}$ from the surface of $\mathrm{TiO}_{2}$ and $\mathrm{SiO}_{2} \cdot \mathrm{SiO}_{2}$ added to $\mathrm{TiO}_{2}$ increased the acidity of the support, which increased the hydroxyl content in the composite films. Consequently, the hydrophilicity and photocatalytic activity of MnPcS$\mathrm{TiO}_{2} @ \mathrm{SiO}_{2}$ were increased [19].

(3) Effect of catalyst dose. In the heterogeneous photocatalytic oxidation reactions, the degradation of toxic organic pollutants is affected by the catalyst dose. Increasing the dose increases the oxidation and degradation rate, but affects light transmission and increases cost [20]. Consequently, it is necessary to meet the catalytic activity requirements with minimum catalyst dose. Increasing the dose of $\mathrm{MnPcS} \mathrm{TiO}_{2} @ \mathrm{SiO}_{2}$ from $0.10 \mathrm{~g} / \mathrm{L}$ (curve a, Figure 6) to $0.20 \mathrm{~g} / \mathrm{L}$ (curve b, Figure 6) increased the RhB degradation rate from $87 \%\left(k=0.0056 \mathrm{~min}^{-1}\right)$ to $99 \%\left(k=0.0075 \mathrm{~min}^{-1}\right)$ within $180 \mathrm{~min}$. However, when the catalyst dose was increased to $0.30 \mathrm{~g} / \mathrm{L}$ (curve c, Figure 6), the degradation rate of $\mathrm{RhB}$ did not increase any more $\left(k=0.0069 \mathrm{~min}^{-1}\right)$. Therefore, under the experimental conditions, the optimal amount of catalyst was $0.20 \mathrm{~g} / \mathrm{L}$.

(4) Effect of $\mathrm{pH}$. The effect of $\mathrm{pH}$ on the photocatalytic activity of $\mathrm{MnPcS}_{-} \mathrm{TiO}_{2} @ \mathrm{SiO}_{2}$ was explored (Figure 7). After visible light irradiation for 240 min of solutions with $\mathrm{pH}$ values of $3.10,5.85,6.88,8.49$ and 10.56 , the $\mathrm{RhB}$ degradation rates were $13 \%$ (curve a), 94\% (curve b), 99\% (curve c), 88\% (curve d) and 5\% (curve e), respectively. Consequently, we can conclude $\mathrm{pH}$ greatly affects the 


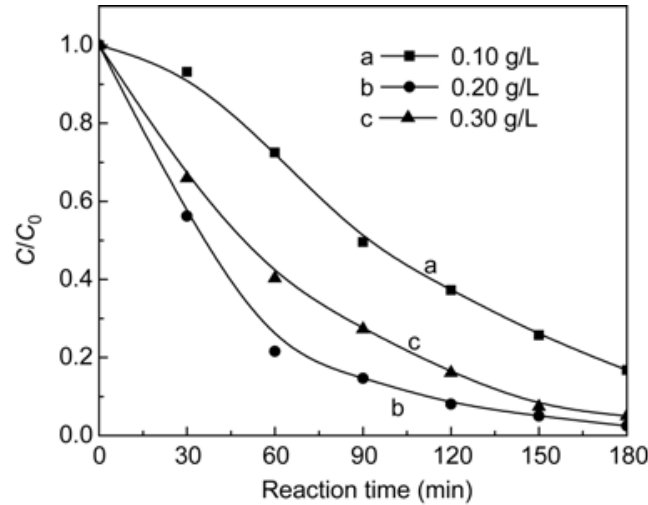

Figure 6 Effect of catalyst dose on the degradation of $\mathrm{RhB}$. [RhB] = $1.10 \times 10^{-5} \mathrm{~mol} / \mathrm{L}$, catalyst loading $=10 \mu \mathrm{mol} / \mathrm{g}$, and $\mathrm{pH} 6.88$.

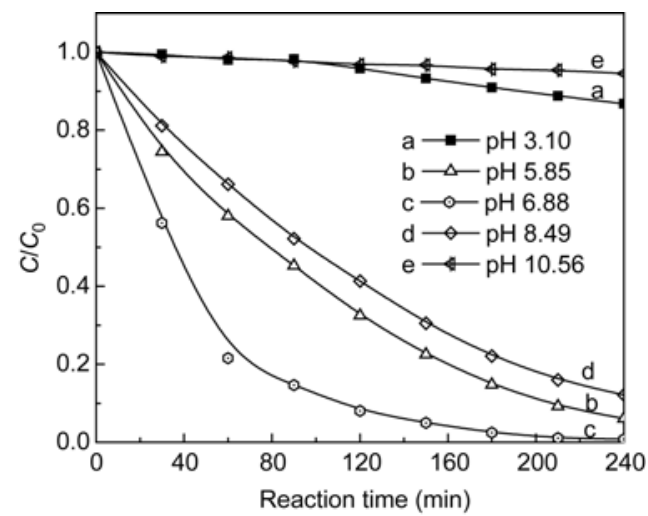

Figure 7 Effect of $\mathrm{pH}$ on $\mathrm{RhB}$ degradation. $[\mathrm{RhB}]=1.10 \times 10^{-5} \mathrm{~mol} / \mathrm{L}$ and $\left[\mathrm{MnPcS}-\mathrm{TiO}_{2} @ \mathrm{SiO}_{2}\right]=0.20 \mathrm{~g} / \mathrm{L}$.

catalytic activity of $\mathrm{MnPcS}_{-} \mathrm{TiO}_{2} @ \mathrm{SiO}_{2}$. In strongly acidic or alkaline solution little RhB was degraded (curves a and e). While the catalyst degraded RhB rapidly (curve c) in neutral conditions. Compared with the traditional Fenton reaction, which is effective only at $\mathrm{pH} \leqslant 3$ [21], the Fenton-like catalyst $\mathrm{MnPcS}_{-}-\mathrm{TiO}_{2} @ \mathrm{SiO}_{2}$ broadened the catalytic $\mathrm{pH}$ range.

(5) Kinetics of RhB photocatalytic degradation under optimal conditions. The kinetics of RhB photocatalytic degradation were determined under the optimal conditions (Figure 8). No catalytic degradation of RhB occurred in the absence of catalyst under visible light irradiation (curve a). In the presence of immobilized $\mathrm{MnPcS}-\mathrm{TiO}_{2} @ \mathrm{SiO}_{2}$ in the dark, minimal degradation was observed (curve b), which indicates that $\mathrm{MnPcS}-\mathrm{TiO}_{2} @ \mathrm{SiO}_{2}$ cannot degrade $\mathrm{RhB}$ in the absence of visible light irradiation. Experiments for the degradation of $\mathrm{RhB}$ in heterogeneous solutions were performed under identical conditions with visible light irradiation. The degradation rates with different compounds were as follows: immobilized $\mathrm{MnPcS}-\mathrm{SiO}_{2}$ (curve c), $k=0.0014$ $\min ^{-1} ; \mathrm{TiO}_{2} @ \mathrm{SiO}_{2}$ (curve d), $k=0.0017 \mathrm{~min}^{-1} ; \mathrm{MnPcS}^{-\mathrm{TiO}_{2}}$ (curve e), $k=0.0037 \mathrm{~min}^{-1}$; and $\mathrm{MnPcS}-\mathrm{TiO}_{2} @ \mathrm{SiO}_{2}$ (curve f), $k=0.0075 \mathrm{~min}^{-1}$. The degradation rate with $\mathrm{MnPcS}-$ $\mathrm{TiO}_{2} @ \mathrm{SiO}_{2}$ was the highest. The photodegradation of $\mathrm{RhB}$ was also evident from the color change on the catalyst surface. Before irradiation, the catalyst was orange-red, due to the adsorption of RhB. The solution became colorless after exposure to visible light for $240 \mathrm{~min}$ (curve f, Figure 8). After irradiation for another $30 \mathrm{~min}$, the color of $\mathrm{MnPcS}$ $\mathrm{TiO}_{2} @ \mathrm{SiO}_{2}$ changed to blue, which is the natural color of $\mathrm{MnPcS}-\mathrm{TiO}_{2} @ \mathrm{SiO}_{2}$. This final color change indicated that $\mathrm{RhB}$ both on the surface of $\mathrm{MnPcS}-\mathrm{TiO}_{2} @ \mathrm{SiO}_{2}$ and in solution was efficiently degraded. However, in the other five cases (curves a-e, Figure 8) the color of $\mathrm{MnPcS}_{-} \mathrm{TiO}_{2} @ \mathrm{SiO}_{2}$ in the RhB solution remained orange-red over the same reaction time.

(6) Catalyst recycling. The stability of the immobilized catalyst is very important for its application in environmental technology. Therefore, the recycling of $\mathrm{MnPcS}-$ $\mathrm{TiO}_{2} @ \mathrm{SiO}_{2}$ was examined for the degradation of $\mathrm{RhB}$ over three consecutive cycles. After each experiment, the solution residue from the photocatalytic degradation was filtered, and the solid washed and dried. The dried catalyst samples were used again for the degradation of RhB with identical experimental conditions. The results (Figure 9), confirmed that the activity of the photocatalyst was maintained. Over the three consecutive cycles, the catalyst showed good stability and its activity was not attenuated. The degradation kinetic constants for cycles one, two and three were 0.0080 , $0.0074,0.0074 \mathrm{~min}^{-1}$, respectively. In addition, during the photoreaction process no $\mathrm{MnPcS}$ was detected in the solution by UV-Vis spectroscopy. These results indicate that $\mathrm{TiO}_{2} @ \mathrm{SiO}_{2}$ and $\mathrm{MnPcS}$ bind together strongly and are not separated by dissolution. The immobilized MnPcS$\mathrm{TiO}_{2} @ \mathrm{SiO}_{2}$ is an efficient and stable photocatalyst for the degradation of toxic organic pollutants in water under visible irradiation.

(7) Determination of $\mathrm{COD}_{\mathrm{Cr}}$. Changes in $\mathrm{COD}_{\mathrm{Cr}}$ reflect the extent of mineralization or degradation of organic pollutants during the catalytic degradation process. We found that $\mathrm{COD}_{\mathrm{Cr}}$ of $\mathrm{RhB}$ reduced as the irradiation time increased, and the $\mathrm{COD}_{\mathrm{Cr}}$ removal rate reached $64.02 \%$ after $24 \mathrm{~h}$ of

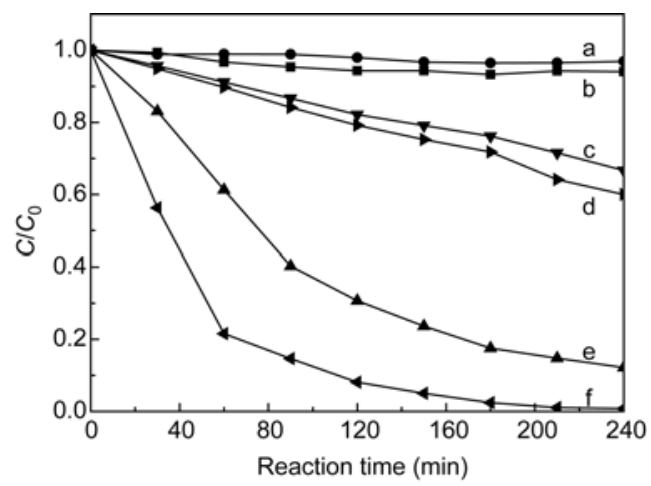

Figure 8 Degradation of RhB by $\mathrm{MnPcS}_{-} \mathrm{TiO}_{2} @ \mathrm{SiO}_{2}(10 \mu \mathrm{mol} / \mathrm{g})$ under

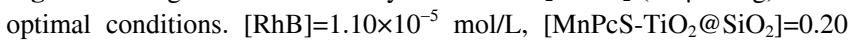
g/L, pH 6.88. a, RhB/vis; b, MnPcS-TiO ${ }_{2} @ \mathrm{SiO}_{2} / \mathrm{RhB} /$ dark; c, MnPcS$\mathrm{SiO}_{2} / \mathrm{RhB} /$ vis; d, $\mathrm{TiO}_{2} @ \mathrm{SiO}_{2} / \mathrm{RhB} /$ vis; e, MnPcS-TiO $/$ /RhB/vis; f, MnPcS$\mathrm{TiO}_{2} @ \mathrm{SiO}_{2} / \mathrm{RhB} /$ vis. 
irradiation $\left(\mathrm{COD}_{\text {initial }}=86.05 \mathrm{mg} / \mathrm{L}\right.$ to $\left.\mathrm{COD}_{\text {final }}=30.96 \mathrm{mg} / \mathrm{L}\right)$. These results indicate that in the presence of $\mathrm{MnPcS}$ $\mathrm{TiO}_{2} @ \mathrm{SiO}_{2}$ and visible light irradiation, the photocatalytic degradation of RhB does not occur by simple bleaching or structural damage. Instead degradation occurs by oxidation of the dye molecules in a mineralization process.

(8) Catalytic oxidation of OPDA. The photocatalytic oxidation of toxic colorless small molecules can be used to evaluate the efficiency of a catalytic system [22]. We investigated colorless OPDA because it can be oxidized to DAPN by $\cdot \mathrm{OH}$ [11], and this conversion is easily detected by monitoring absorbance changes at $453 \mathrm{~nm}$. We observed a small amount of OPDA to DAPN oxidization under visible light irradiation for $560 \mathrm{~min}$ (curve a, Figure 10). The concentration of DAPN increased significantly when

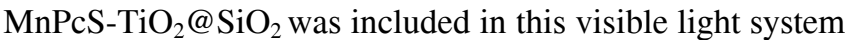
(curve b, Figure 10). These results indicate that the presence of visible light alone produces only a small amount of $\cdot \mathrm{OH}$ for OPDA oxidation. However, under otherwise identical conditions, the system containing $\mathrm{MnPcS}-\mathrm{TiO}_{2} @ \mathrm{SiO}_{2}$ produces a large amount of $\cdot \mathrm{OH}$ to oxidize most of the OPDA to DAPN. The catalytic oxidation of OPDA by MnPcS$\mathrm{TiO}_{2} @ \mathrm{SiO}_{2}$ demonstrates that the immobilized catalysis is promising for the oxidation of colorless organic pollutants

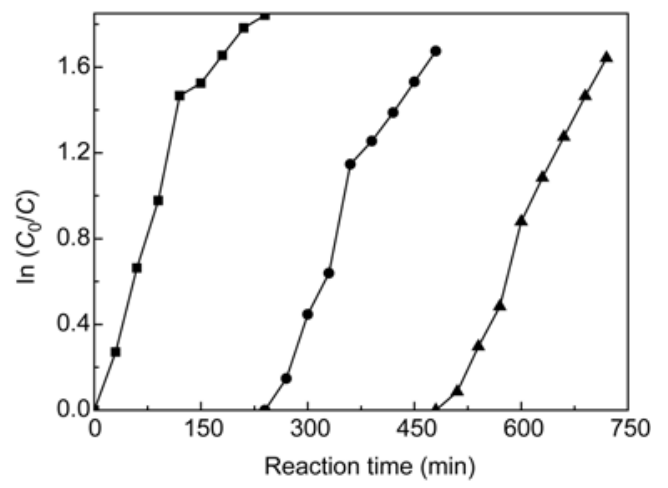

Figure 9 Three consecutive cycles of photodegradation with $\mathrm{MnPcS}$ $\mathrm{TiO}_{2} @ \mathrm{SiO}_{2}(10 \mu \mathrm{mol} / \mathrm{g})$. [RhB $]=1.10 \times 10^{-5} \mathrm{~mol} / \mathrm{L},\left[\mathrm{MnPcS}-\mathrm{TiO}_{2} @ \mathrm{SiO}_{2}\right]=$ $0.20 \mathrm{~g} / \mathrm{L}$ and $\mathrm{pH} 6.88$.

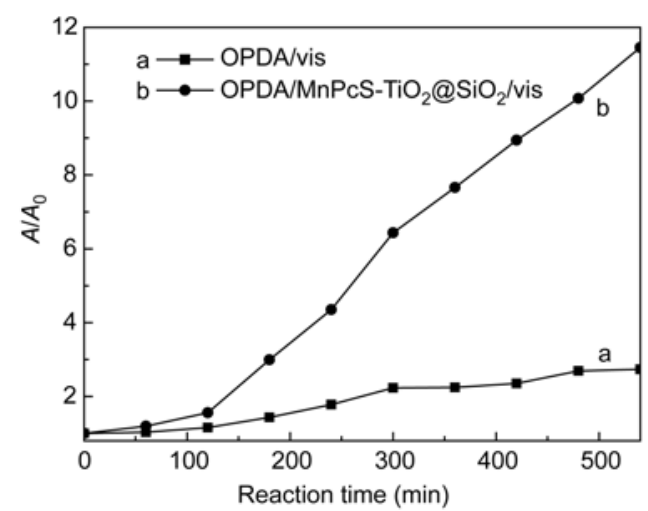

Figure 10 Catalytic oxidation of OPDA $\left(3.00 \times 10^{-3} \mathrm{~mol} / \mathrm{L}\right)$ by $\mathrm{MnPcS}$ $\mathrm{TiO}_{2} @ \mathrm{SiO}_{2}(0.20 \mathrm{~g} / \mathrm{L})$. under visible light.

(9) Photodegradation mechanism. The photocatalytic behavior of $\mathrm{MnPcS}$ supported on $\mathrm{TiO}_{2} @ \mathrm{SiO}_{2}$ can be explained using the energy levels of the molecular semiconductor $(\mathrm{MnPcS})$ and oxide semiconductor $\left(\mathrm{TiO}_{2} @ \mathrm{SiO}_{2}\right)$ couple. The band gap energy of $\mathrm{MnPcS}$ is about $2.0 \mathrm{eV}$ [23], while that of $\mathrm{TiO}_{2} @ \mathrm{SiO}_{2}$ is equal to $\mathrm{TiO}_{2}$ at $3.2 \mathrm{eV}$. The conduction band of $\mathrm{MnPcS}$ is more cathodic than the conduction band of $\mathrm{TiO}_{2} @ \mathrm{SiO}_{2}$, while the valence band of $\mathrm{TiO}_{2} @ \mathrm{SiO}_{2}$ is much more positive than the corresponding band of MnPcS [24]. Upon irradiation with visible light, it is possible to excite $\mathrm{MnPcS}$ (eq. (1)), which effects charge transition into the conduction band of its excited state (eq. (2)). The $\mathrm{Mn}^{\mathrm{II}} \mathrm{PcS}$ is oxidized to $\mathrm{Mn}^{\mathrm{III}} \mathrm{PcS}$ (eq. (3)). The quantum yield of the redox process catalyzed by the molecular semiconductor is not high [25], which is a prerequisite for accomplishing electron transfer into the conduction band of $\mathrm{TiO}_{2} @ \mathrm{SiO}_{2}$. The probability of electron transfer from the conduction band of excited MnPcS to the conduction band of $\mathrm{TiO}_{2} @ \mathrm{SiO}_{2}$ is higher. The intercomponent electron transfer and the catalytic redox are represented schematically in Figure 11. The electrons in the conduction bands of both $\mathrm{MnPcS}$ and $\mathrm{TiO}_{2} @ \mathrm{SiO}_{2}$ are transferred to molecular oxygen $\left(\mathrm{O}_{2}\right)$, which leads to $\cdot \mathrm{OH}$ and $\mathrm{O}_{2}^{-\cdot}$ formation in the system. The $\cdot \mathrm{OH}$ and $\mathrm{O}_{2}^{-\cdot}$ formation has been proved qualitatively by electron spin resonance (ESR). ESR is a modern separation technique used to determine shortlived free radicals. It can be useful to elucidate the mechanism of photocatalytic reactions [26]. To detect and identify short-lived free radicals, the non-saturated anti-magnetic material (spin trapping agent) DMPO was added to MnPcS$\mathrm{TiO}_{2} @ \mathrm{SiO}_{2}$ with visible light irradiation. This generates long-lived spin adducts, which are used to determine the radicals. The measurements were conducted under in-situ laser $(\lambda=532 \mathrm{~nm})$ irradiation. Figure 12 represents the ESR signals of the DMPO- $\cdot \mathrm{OH}$ adducts in water and DMPO$\mathrm{O}_{2}^{-} \cdot$ adducts in methanol both in the dark and with photocatalytic reaction. No ESR signals were observed when the reaction was performed in the dark either in aqueous solution or in methanol. Under visible light irradiation, characteristic quartet peaks of DMPO- $\cdot \mathrm{OH}$ adduct in aqueous

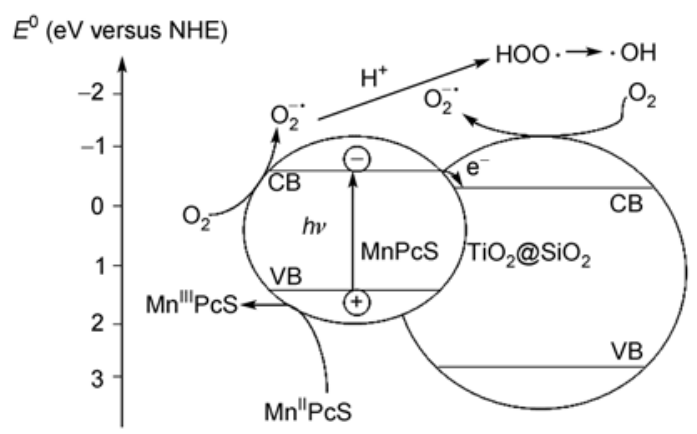

Figure 11 Proposed photodegradation mechanism in the aqueous $\mathrm{MnPcS}-\mathrm{TiO}_{2} @ \mathrm{SiO}_{2}$ system under visible light irradiation. 
(a)
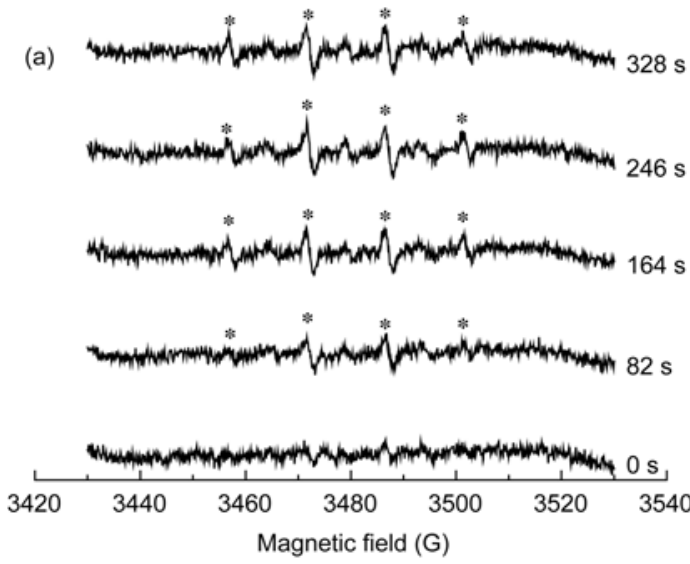

(b)
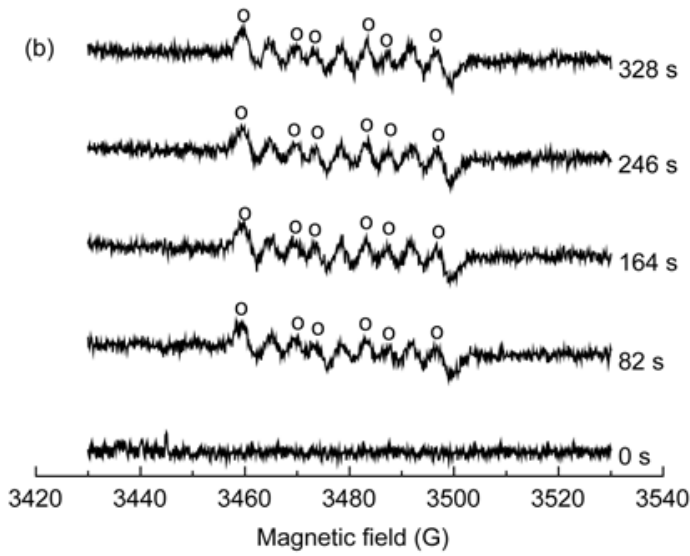

Figure 12 ESR signals of the DMPO- $\cdot \mathrm{OH}$ adducts in water (a) and DMPO- $\mathrm{O}_{2}^{-}$adducts in methanol (b). [DMPO] $=0.04 \mathrm{~mol} / \mathrm{L}$, and $[\mathrm{MnPcS}-$ $\left.\mathrm{TiO}_{2} @ \mathrm{SiO}_{2}\right]=0.20 \mathrm{~g} / \mathrm{L}$.

solution [27] with an intensity ratio of $1: 2: 2: 1$ (Figure 12 (a)) appeared rapidly, and the signal stabilized after $82 \mathrm{~s}$ of irradiation. This result indicates that the photocatalytic reaction involves $\cdot \mathrm{OH}$, which is a catalytic reaction intermediate species. In methanol, the characteristic peaks of DMPO-O ${ }_{2}^{-\cdot}$ adduct [26] were observed under visible light irradiation (Figure 12(b)). The observed peaks were similar to those reported by Zhao et al [28]. These results indicate that the photocatalyst functions effectively by rapidly generating $\cdot \mathrm{OH}$ and $\mathrm{O}_{2}^{-}$, which are predominant in the system under visible light.

$$
\begin{aligned}
& \mathrm{Mn}^{\mathrm{II}} \mathrm{PcS}+h v \rightarrow \mathrm{Mn}^{\mathrm{II}} \mathrm{PcS}^{*} \\
& \mathrm{Mn}^{\mathrm{II}} \mathrm{PcS}^{*} \rightarrow \mathrm{Mn}^{\mathrm{II}}\left(\mathrm{Pc}^{+}+\mathrm{e}_{\mathrm{CB}}{ }^{-}\right) \mathrm{S} \\
& \mathrm{Mn}^{\mathrm{II}}\left(\mathrm{Pc}^{+}+\mathrm{e}_{\mathrm{CB}}{ }^{-}\right) \mathrm{S}+\mathrm{O}_{2} \rightarrow \mathrm{Mn}^{\mathrm{II}} \mathrm{PcS}+\mathrm{O}_{2}^{-} \cdot
\end{aligned}
$$

\section{Conclusion}

The photocatalytic oxidation system of immobilized MnPcS$\mathrm{TiO}_{2} @ \mathrm{SiO}_{2}$ efficiently photodegraded the nonbiodegradable dye $\mathrm{RhB}$ in an aqueous solution. The $\mathrm{TiO}_{2}$ and $\mathrm{SiO}_{2}$ composite enhanced the binding of MnPcS to the support,

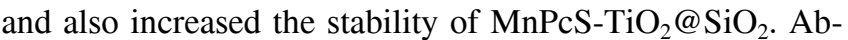
solute ethanol used as loading solvent improved the dispersion and increased the catalytic activity of $\mathrm{MnPcS}$ $\mathrm{TiO}_{2} @ \mathrm{SiO}_{2}$. Compared with traditional Fenton's reagent, the solid-state catalyst broadened the range of $\mathrm{pH}$ adaptation. Under visible light irradiation at $\mathrm{pH} 6.88$, the catalyst degraded $\mathrm{RhB}$ rapidly. The $\mathrm{COD}_{\mathrm{Cr}}$ removal rate of $\mathrm{RhB}$ reached $64.02 \%$ after $24 \mathrm{~h}$. The photocatalyst was easily collected from the reaction solution by simple filtration, and could be reused for photocatalytic experiments with little loss of activity. The high photocatalytic activity of the $\mathrm{MnPcS}$ deposited on $\mathrm{TiO}_{2} @ \mathrm{SiO}_{2}$ is explained by electron transfer from the conduction band of the excited MnPcS to the conduction band of the support.

This work was supported by the National Natural Science Foundation of China (20877048), the National Basic Research Program of China (2008CB417206) and the Innovation Group Project of Hubei Provincial Natural Science Foundation (2009CDA020).

1 Tao X, Ma W H, Zhao J C, et al. A novel approach for the oxidative degradation of organic pollutants in aqueous solutions mediated by iron tetrasulfophthalocyanine under visible light radiation. Chem Eur J, 2002, 8: 1321-1326

2 Tao X, Ma W H, Zhao J C, et al. Efficient degradation of organic pollutants mediated by immobilized iron tetrasulfophthalocyanine under visible irradiation. Chem Commun, 2003, 80-81

3 Luo Y J, Luo G F, Huang Y P, et al. Advances on the simulation of peroxides and its application (in Chinese). J Instum Anal, 2004, 23: 136-142

4 Ilive V, Ileva A, Bilyarska L. Oxidation and photooxidation of sulfur-containing compounds in the presence of immobilized phthalocyanine complexes. J Mol Catal A: Chem, 1997, 126: 99-108

5 Iliev V, Prahov L, Bilyarska L, et al. Oxidation and photooxidation of sulfide and thiosulfate ions catalyzed by transition metal chalcogenides and phthalocyanine complexes. J Mol Catal A: Chem, 2000, 151: $161-169$

6 Xiong Z G, Xu Y M. Immobilization of palladium phthalocyaninesulfonate onto anionic clay for sorption and oxidation of 2, 4, 6-trichlorophenol under visible light irradiation. Chem Mater, 2007, 19: 14521458

7 Chen R F, Zhang C X, Deng J, et al. Preparation and photocatalytic activity of $\mathrm{Cu}^{2+}$-doped $\mathrm{TiO}_{2} / \mathrm{SiO}_{2}$. Int J Miner Metall Mater, 2009, 16: 220-225

8 Chen Y F, Lee C Y, Yeng M Y, et al. The effect of calcination temperature on the crystallinity of $\mathrm{TiO}_{2}$ nanopowders. J Cryst Growth, 2003, 247: 363-370

9 Ji H W, Ma W H, Zhao J C, et al. Advances on visible light induced photocatalytic of $\mathrm{TiO}_{2}$ (in Chinese). Chinese Sci Bull (Chinese Ver), 2003, 48: 2199-2204

10 Wang S, Wang T, Chen W X, et al. Phase-selectivity photocatalysis: A new approach in organic pollutants photodecomposition by nanovoid core $\left(\mathrm{TiO}_{2}\right) /$ shell $\left(\mathrm{SiO}_{2}\right)$ nanoparticles. Chem Commum, 2008, 32: 3756-3758

11 Fang Y F, Deng A P, Huang Y P. Determination of hydroxyl radical in Fenton system. Chin Chem Lett, 2009, 20: 1235-1240

12 Huang Y P, Cai R X, Huang H P. Studies on the fluorescence enhancement of reverse micelle on 2,3-diaminophenazine (in Chinese). Chem J Chin Univ, 1999, 20: 1031-1035

13 Zhao C, Huang Y P, Fang Y F, et al. Fe ${ }^{3+}$ supported on zeolite as effective catalyst for the heterogeneous oxidation of rhodamine $\mathrm{B}(\mathrm{RhB})$ under visible irradiation (in Chinese). Environ Chem, 2008, 27: 6-10 
14 Liang Q, Han A X, Zhang F S. Synthesis and application of manganese ( II ) tetrasulfophthalocyanine (in Chinese). Chin J Appl Chem, 2004, 21: 1290-1294

15 Hamza A, Srinivas D. Selective oxidation of benzyl alcohol over copper phthalocyanine immobilized on MCM-41. Catal Lett, 2009, 128: 434-442

16 Sun A H, Xiong Z G, Xu Y M. Removal of malodorous organic sulfides with molecular oxygen and visible light over metalphthalocyanine. J Hazard Mater, 2008, 152: 191-195

$17 \mathrm{Xu} \mathrm{Y} \mathrm{M,} \mathrm{Hu} \mathrm{M} \mathrm{Q,} \mathrm{Chen} \mathrm{Z} \mathrm{X,} \mathrm{et} \mathrm{al.} \mathrm{Mineralization} \mathrm{of} \mathrm{4-chlorophenol}$ under visible light irradiation in the presence of aluminum and zinc phthalocyaninesulfonates. Chin J Chem, 2003, 21: 1092-1097

18 Ozoemena K, Kuznetsova N, Nyokong T. Photosensitized transformation of 4-chlorophenol in the presence of aggregated and non-aggregated metallophthalocyanines. J Photochem Photobiol A: Chem, 2001, 139: 217-224

19 Guan K. Relationship between photocatalytic activity, hydrophilicity and self-cleaning effect of $\mathrm{TiO}_{2} / \mathrm{SiO}_{2}$ films. Surf Coat Technol, 2005, 191: 155-160

20 Zanjanchi M A, Ebrahimian A, Arvand M. Sulphonated cobalt phthalocyanine-MCM-41: An active photocatalyst for degradation of 2, 4-dichlorophenol. J Hazard Mater, 2010, 175: 992-1000

21 Zhao C, Huang Y P, Fang Y F, et al. Visible light-induced degradation of organic pollutants using $\mathrm{Fe}$ (II) supported on silica gel as an effective catalyst. Chinese Sci Bull, 2008, 53: 1497-1502

22 Deng A P, Huang Y P, Fang Y F, et al. Preparation of $\mathrm{TiO}_{2}$ nanotube and photodegradation of toxic organic pollutants (in Chinese). Environ Chem, 2009, 28: 202-205

23 Simon J, Andre J J. Molecular Semiconductors. Photoelectrical Properties and Solar Cells. Berlin: Springer, 1985

24 Fujishima A, Rao T N, Tryk D A. Titanium dioxide photocatalysis. J Photochem Photobiol C: Photochem, 2000, 1: 1-21

25 Iliev V, Tomova D, Bilyarska L, et al. Phthalocyanine modified $\mathrm{TiO}_{2}$ or $\mathrm{WO}_{3}$-catalysts for photooxidation of sulfide and thiosulfate ions upon irradiation with visible light. J Photochem Photobiol A: Chem, 2003, 159: 281-287

$26 \mathrm{Wu} \mathrm{T} \mathrm{X,} \mathrm{Lin} \mathrm{T}$, Zhao $\mathrm{J} \mathrm{C}$, et al. $\mathrm{TiO}_{2}$-assisted photodegradation of dyes. 9. Photooxidation of a squarylium cyanine dye in aqueous dispersions under visible light irradiation. Environ Sci Technol, 1999, 33: $1379-1387$

27 Ma J H, Ma W H, Zhao J C, et al. Fenton degradation of organic pollutants in the presence of low-molecular-weight organic acids: Cooperative effect of quinone and visible light. Environ Sci Technol, 2006, 40: 618-624

28 Liu G M, Zhao J C, Hidaka H. ESR spin-trapping detection of radical intermediates in the $\mathrm{TiO}_{2}$-assisted photooxidation of sulforhodamine B under visible irradiation. J Photochem Photobiol A: Chem, 2000, 133: $83-88$

Open Access This article is distributed under the terms of the Creative Commons Attribution License which permits any use, distribution, and reproduction in any medium, provided the original author(s) and source are credited. 